\title{
Editorial
}

\section{Demokrasi Deliberatif: Dari Wacana ke Kerangka Hukum}

Wacana demokrasi deliberatif - walaupun agak terlambat - mulai masuk dalam khazanah keilmuan Indonesia setelah runtuhnya Orde Baru (Fahrul Muzaqqi, 2013: 123), sekira tahun 2000-an. Dalam hal ini, demokrasi deliberatif mengacu pada gagasan bentuk pemerintahan di mana para warga negara yang bebas dan sederajat, memberikan pembenaran proses pengambilan keputusan di mana mereka memberikan alasan-alasan lain secara timbal balik dapat diterima dan dapat diakses dengan tujuan mencapai kesimpulan-kesimpulan yang mengikat saat ini kepada setiap warga negara namun terbuka untuk digugat di kemudian hari (Gutman dan Thompson dalam Bilal Dewansyah, 2015: 24). Meskipun demikian, gagasan tersebut baru mulai mengemuka pada tahun 2000 dengan muncul beberapa literatur, seperti artikel dan buku yang ditulis F. Budi Hardiman (2004 dan 2009) dalam perspektif Habermasian.

Perkembangan di Indonesia selanjutnya, demokrasi deliberatif lebih banyak digunakan sebagai pisau analisa untuk mengkritisi berbagai aspek hubungan negara dengan rakyat, seperti persoalan partai politik dari perspektif demokrasi deliberatif (Indra J. Piliang: 2008), atau demokrasi deliberatif sebagai kajian teoritik, terutama untuk menggagasnya sebagai tatanan penting dalam sistem politik Indonesia, seperti gagasan institusionalisasi demokrasi deliberatif di Indonesia (Muhammad Faishal: 2007). Memang ada upaya teoritik yang mengabstraksi beberapa praktik diskursus publik sebagai praktik demokrasi deliberatif di Indonesia (Bilal Dewansyah: 2011), namun hampir tidak ada yang mengangkat isu hukum demokrasi deliberatif.

Perkembangan di dunia western, demokrasi deliberatif bukan hanya sudah bertransformasi pada praktik institusional seperti polling deliberatif-nya James S. Fiskhin (2009), atau praktik townhall meeting di berbagai pemerintahan lokal di Amerika Serikat, namun juga sudah merambah pada isu hukum: hukum demokrasi deliberatif. Dalam konteks ini, diskursus hukum demokrasi deliberatif (the law of deliberative democracy) mengelaborasi peran hukum dalam demokrasi deliberatif, baik hukum sebagai prakondisi terciptanya demokrasi deliberatif atau mungkin hukum secara tidak langsung mengarahkan pada budaya deliberasi atau justru sebaliknya, anti terhadap deliberasi (Ron Levy: 2013, 356-357).

Upaya para scholars untuk membahas isu tersebut secara kolektif telah dimulai sejak diadakannya "Symposium: The Law of Deliberative Democracy" di New York University dan King's College London pada 5-9 April 2013. Para pakar pada symposium tersebut lebih banyak memfokuskan bahasan hukum dan demokrasi 
deliberatif dengan objek Hukum Pemilu (Election Law). Hukum Pemilu tampaknya dijadikan sebagai 'objek uji coba' diskursus hukum dalam demokrasi deliberatif. Ada dua pandangan utama peran hukum dalam konteks Hukum Pemilu dalam momen tersebut. Ada yang sepakat bahwa demokrasi deliberatif dalam Pemilu berupa praktik deliberatif pembentukan undang-undang Pemilu oleh Forum Warga, seperti pengalaman Citizen Assembly di provinsi British Columbia (Kanada) yang merancang undang-undang Pemilu. Pandangan ini menolak praktik demokrasi deliberatif dalam pelaksanaan Pemilu, karena dialog dan pertukaran argumen masa Pemilu, seperti saat kampanye misalnya, lebih bersifat adversarial, ketimbang rasional.

Pandangan kedua justru menganggap demokrasi deliberatif harus dipraktikkan dalam masa Pemilu, seperti saat kampanye atau dialog dengan pasangan calon, dan hukum Pemilu harus mengakomodasinya dalam aturan yang compulsory. Terlepas dari perdebatan tersebut, hubungan hukum dengan demokrasi deliberatif bukan hanya soal Pemilu, namun juga dapat merambah pada bidang kehidupan bernegara lainnya. Namun demikian, yang paling penting dalam diskursus hukum demokrasi deliberatif yaitu ajakan para ahli hukum untuk mulai mengkaji berbagai aspek hukum dalam demokrasi deliberatif, bahkan mendorong pengaturannya dalam hukum positif.

Memang di Indonesia, praktik demokrasi deliberatif masih jarang dapat dilihat mata, sehingga upaya mengkajinya, pasti jarang, apalagi dari aspek hukum. Praktik deliberasi demokratis pun lebih banyak merupakan inisiasi masyarakat sipil, ketimbang perintah norma hukum, seperti praktik Forum Konstituen dalam Pilkada Kabupaten Bandung 2010. Bahkan ada yang menganggap, satu-satunya praktik demokrasi deliberatif di Indonesia yang diatur dalam kerangka hukum hanya ada tingkat pada pemerintahan lokal di Kabupaten Sumedang melalui keberadaan Forum Delegasi Musrenbang (FDM) yang diatur dalam Peraturan Daerah Sumedang No. 1 Tahun 2007 tentang Prosedur Perencanaan dan Penganggaran Daerah Kabupaten Sumedang dalam hal proses penyusunan dan implementasi APBD (Bilal Dewansyah: 2011, 92).

Kondisi tersebut memiliki dua sisi. Di satu sisi, demokrasi deliberatif belum menjadi praktik umum keterlibatan publik dalam pengambilan kebijakan publik atau keputusan politik di Indonesia. Di sisi lain, praktik demokrasi Indonesia yang 'sedang tumbuh' justru menjadi lapangan potensial untuk mengembangkan konsepsi praktikal demokrasi deliberatif, termasuk upaya pengaturannya dalam hukum. Dengan kata lain, ini adalah tantangan bagi para ahli hukum Indonesia, khususnya pada ranah hukum publik, untuk meneliti, mengembangkan dan bahkan mendorong institusionalisasi demokrasi deliberatif dalam hukum positif. 
10 artikel terpilih dalam edisi kali ini membahas berbagai isu hukum yang beragam. Artikel kehormatan dari Prof. Tarsisius Muwardji membahas penjaminan hak pengelolaan daratan perairan kepulauan. Ema Rahmawati dan Rai Mantili membahas lembaga alternatif penyelesaian sengketa di sektor jasa keuangan. Davina Oktivana menulis gagasan tentang urgensi revisi undang-undang landas kontinen Indonesia. Bilal Dewansyah dan M. Adnan Yazar Zulfikar mengelaborasi sebab dan konsekuensi dianutnya kembali (reafirmasi) sistem pemerintahan presidensial dalam perubahan UUD 1945 berikut model pertanggungjawabannya. Laurensius Arliman Simbolon menulis partisipasi masyarakat di dalam perlindungan anak yang berkelanjutan sebagai bentuk kesadaran hukum. Sementara itu, Andrey Sujatmoko menganalisis salah satu isu di bidang hak asasi manusia mengenai hak atas pemulihan korban pelanggaran berat hak asasi manusia serta prinsip tanggung jawab negara dalam hukum internasional.

Selanjutnya Russel Butarbutar membahas pertanggungjawaban pidana partai politik dalam tindak pidana korupsi. Agus Surono memberikan rekomendasi dalam menumbuhkan budaya anti korupsi bagi siswa dan mahasiswa sebagai upaya pencegahan tindak pidana korupsi. Canggih Prabowo mengkritisi salah satu persoalan penyelenggaraan urusan pemerintahan pilihan pasca Undang-Undang Nomor 23 Tahun 2014 tentang Pemerintahan Daerah dengan mengambil kasus pengusahaan panas bumi dalam kawasan hutan di Jawa Barat. Terakhir, Ahmad Hunaeni Zulkarnaen dan Tanti Kirana Utami membahas persoalan eksistensi pekerja dalam sistem hubungan industrial di Indonesia dan pola integralistik demokrasi ekonomi Pancasila. Selamat membaca. 